\title{
TÜRKIYAT MECMUASI
}

\section{Doğu Akdeniz’de Memlûk-Haçlı Mücadelesinde Trablus Şehri}

\section{Tripoli City in the East Mediterranean in the Fight of Mamluk-Crusader}

\author{
Altan ÇETIN ${ }^{1}$
}

'Sorumlu yazar/Corresponding author: Altan Çetin (Prof. Dr.),

Anadolu Üniversitesi, Edebiyat Fakültesi, Tarih Bölümü, Eskişehir, Türkiye

E-posta: altancetin@anadolu.edu.tr

ORCID: 0000-0002-2029-1373

Başvuru/Submitted: 05.09.2021

Revizyon Talebi/Revision Requested:

17.09.2021

Son Revizyon/Last Revision Received:

28.09.2021

Kabul/Accepted: 13.02.2021

Online Yayın/Published Online: 05.04.2021

Atıf/Citation: Cetin, Altan. "Doğu Akdeniz'de Memlûk-Haçlı Mücadelesinde Trablus Şehri." Türkiyat Mecmuası-Journal of Turkology 31, 1 (2021): $185-197$.

https://doi.org/10.26650/iuturkiyat.793525

\section{öz}

Doğu Akdeniz İslâm'ın buraya gelişinden itibaren tarihinde yeni bir mücadele safhasını yaşadı. Memlûkler Mısır ve Suriye'de hâkim olmalarıyla birlikte bölgelerinde yaşanan pek çok rekabet gibi Doğu Akdeniz mücadelesine de taraf oldular. Bu süreçte Mısır ve Suriye sahilleri ve burada bulunan şehirler Memlûk tarihi boyunca muhtelif saldırı ve mücadeleye şahit oldu. Haçlı Seferlerinin klasik çağı kapandıktan sonra 14. asır Haçlı saldırılarının yeni bir safhasını teşkil eder. Balkanlar, Ege ve Doğu Akdeniz bu asır boyunca Haçlı saldırılarına hedef oldu. Memlûkler işte bu asırda vaki Haçlı saldırılarını göğüsleyerek Suriye ve Mısır sahillerine gelen saldırıları ters yüz ettiler. Buna ilave olarak 13. asır boyunca Memlûklerin Suriye sahillerinde yer alan Trablus, Akka gibi son kaleleri ele geçirdikleri görülmektedir. Yine Ermeni Baronluğu gibi yapıları yıkıp nihayet Kıbrıs Adası'nı fethettikleri anlaşılmaktadır. Böylelikle Doğu Akdeniz'de yaşanan mücadeleyi başarıyla tamamlayarak Haçlıları bölgeden uzaklaştırmışlardır. İşte bu mücadele meyanında Bilâdü'ş-Şâm/Suriye'de yer alan Memlûk şehirlerinin önde gelenlerinden biri Trablus idi. Burada yer alan kontluğun yıkılması sonrasında Haçlıların bölgeye saldıılarında ana hedeflerden birisi olacak olan şehir askeri ve ekonomik değeri ile vazgeçilmez bir konum ve değerde idi. Haçılır 14. asır saldırılarında yaptıkları mütemadî hücumlarında Trablus şehrini de mahsusen hedefe koydular. İşte bu çalışmada, Trablus'a Haçlıların bu devirdeki saldırıları ve buna Memlûklerin mukabil savunmaları ele alınacaktır. Antakya fethi ile Baybars zamanında başlayan süpürme harekâtının Trablus ve Akka ile tamamlanması sürecinde 14. asırda Trablus'a vaki saldırıları Kıbrıs'ın fethine kadar sürecek olan mücadele tarihinin önemli bir safhası olarak bu ara dönemin ele alınmasıyla Haçlı-Memlûk rekabetine dair müteselsil çalışmalarımızın bir bölümü daha tamamlanmış olmaktadır.

Anahtar kelimeler: Memlûkler, Haçlılar, Trablus, Doğu Akdeniz, İslâm

\section{ABSTRACT}

The Eastern Mediterranean has experienced a new phase of struggle in its history since the arrival of Islam. With the Mamluks dominating in Egypt-Syria, they became a party to the Eastern Mediterranean Struggle such as many rivalries in their regions. Throughout Mamluk history, the coasts of Egypt and Syria and the cities located here witnessed various attacks and struggles. After the classical era of the Crusades ends, the 14th century constitutes a new phase of the Crusader 
attacks. Throughout this century, the Balkans, the Aegean, and the Eastern Mediterranean are the targets of Crusader attacks, and in this century, the Mamluks withstand the Crusader attacks and reverse the attacks on the coasts of Syria and Egypt. In the 13th century, the Mamluks captured the last fortresses of Tripoli and Akka, on the Syrian coast, demolished structures such as the Armenian Barony, and successfully completed this struggle in the Eastern Mediterranean with the conquest of the island of Cyprus and removed the Crusaders from the region. In the middle of this struggle, Tripoli was a leading Mamluk city in Bilad al-Damascus, Syria. The city, a main target of the Crusaders' attacks on the region after the collapse of the county located here, had an indispensable position and value because of its military and economic value. The Crusaders also targeted the city of Tripoli in their continuous attacks during the 14th-century attacks. In this study, the Crusaders'attacks on Tripoli in this period and the corresponding defenses of the Mamluks are discussed. In the process of completing the sweeping operation that started with the conquest of Antakya with the conquest of Baybars with Tripoli and Acre, the attacks on Tripoli in the 14th century were an important phase in the history of the struggle that continues until the conquest of Cyprus and some of our joint work on the Crusader-Mamluk rivalry has been completed..

Keywords: Mamluks, Crusaders, Tripoli, East Mediterranean, Islam

\section{EXTENDED ABSTRACT}

It represents the period in which the East underwent a new wave of attacks in the history of the 14th century Crusades. The target of these attacks in the Eastern Mediterranean is the coasts of Anatolia, Syria, and Egypt. In the 14th century, the Islamic world exhibited strength in this attack on the Asian front's Ottoman Empire and the various principalities, while the Egyptian-Syrian party or there were the Mamluks of Egypt, Turkey States. Although this attack was met by the Ottomans in Nigbolu, Aydinogullari and other beys on the Aegean shores stand against the attacks, and finally, the Mamluks successfully break this wave on the EgyptianSyrian front. Tripoli (Tripoli) is one of the cities attacked on the Syrian front in this century. The city that will be referred to is Tripoli because it is mentioned in the sources in the working text as Tripoli, which is in Lebanon today. Because this region is one of the last captured by the Crusaders, a main goal of the Crusaders in terms of becoming a power on land is capturing this city. Tripoli is remembered for being attacked intensely during the Mamluk-Crusader struggle because of the capture of Cyprus by the Mamluks in the 13th century.

Sultan al-Malik al-Mansûr Kalavûn set off for Tripoli in 1289, leaving his son Eşref Halil as crown prince and Emir Beydemir as regent and vizier in Cairo. At the same time, orders were sent to the forces in Bilad al-Damascus to prepare for this time. The Sultan, who visited Damascus first, headed toward Tripoli from there. Additionally, eight shavani-type ships were sent to Tripoli as aid against the siege from Cyprus, which became an important base of the Crusaders. During the siege, the Sultan also ordered the catapults to be erected and the sewers to start working on the walls. The city was captured after 34 days of siege. Additionally, 19 catapults were erected toward the city. Much loot and many captives were obtained when the city was captured. The Sultan ordered the city to be demolished in accordance with the custom. Tripoli was large and surrounded by fortified walls; the width of the city walls was such that three horsemen could move side by side. The inhabitants of this settled city were advanced weavers, and in the city, there were four thousand weaving tools. This situation 
made this city important for more than its military. During this expedition, in addition to Tripoli, Beirut, and Cebele were captured. After Tripoli was captured, five hundred soldiers, ten people from the Tablhane orders, and fifteen people from the Aşarat orders were sent here. Ictas were distributed in the city. Subsequently, the Muslims built a new city near the river. In 1289, Sultan Kalavûn conquered the city, and some of the townspeople fled to Cyprus by ship. Thus, the last structure that the Crusaders built in the world of Islam was also destroyed. After Antakya, the Mamluks destroyed the last great Crusader political entity and brought the Crusader presence on the Syrian continent to the point of extinction. During the post-conquest period, Sultan al-Mansûr Kalavûn had Tripoli's walls demolished so that they would not be targeted and used by the new Crusades, and then left.

The 14th century is when the Crusaders attacked the Anatolian, Egyptian, and Syrian coasts in the Eastern Mediterranean with the idea of a new Crusade. Tripoli became one of the main targets of these attacks. After the Crusaders poured into the sea from Syria, a Crusader group that attacked Tripoli in 1334 was defeated, many of them were killed, prisoners were taken, and their goods were seized. In 1365, the Crusaders attacked Tripoli again. They seized the ships belonging to the Muslims in the port of Tripoli, burned the ships, and captured three people. When the Crusaders' attack on Alexandria failed, Tripoli became their main target. Because of its proximity to the island of Cyprus, location in the middle of the Damascus coast, and commercial importance, the city became strategically important for the Crusaders. Tripoli, an important trade center, continued to be open to European trade in the 15th century, had tight commercial relations with France and Genoa, and was the main stopover for merchant ships in the Eastern Mediterranean. Silk fabrics were a main export item. States managing Mediterranean trade had one representative there. The Crusaders wanted to inflict multifaceted damage on the Islamic power in the Eastern Mediterranean by attacking places of economic and political significance.

The Crusaders did not stand still, and the king of Cyprus, from the Lusignan dynasty, corresponded with local information sources in Tripoli about the city's possibilities and opportunities for seizure. Completing these preparations, the king finally went on an expedition to the city in 1367 with a fleet of various types of ships ranging from 130 to 200 . Within these forces, R ... 


\section{Giriş/Introduction}

14. asır, Haçlı Seferleri tarihinde Doğu'nun yeni bir saldırı dalgasına uğradığı devreyi temsil eder. Bu saldırıların Doğu Akdeniz'de hedefi Anadolu, Suriye ve Mısır kıyıları olacaktır. 14. asırda, İslâm dünyasının bu saldırıya mukavemetinde Anadolu cephesinde, Osmanlı Devleti ve muhtelif beylikler yer alırken Mısır-Suriye tarafında ise Memlûkler yahut Mısır Türk Devleti bulunuyordu. Niğbolu'da bu saldırı Osmanlılar tarafından karşılanırken Ege kıyılarında Aydınoğulları ve diğer beyler hucümlara karşı durmuş nihayet Mısır Suriye cephesinde Memlûkler bu dalgayı başarıyla kıracaklardır. Bu asırda Suriye cephesinde taarruza uğrayan şehirlerinden biri de Trablus (Trablusşam) olacaktır. Çalışma metninde kaynaklarda geçtiği şekliyle Trablus olarak zikredilecek olan şehir bugün Lübnan'da bulunan Trablusşam'dır. Buranın Haçlılar elinden alınan son bölgelerden olduğu düşünüldüğünde Haçlıların yeniden karada güç olmak noktasından en önemli hedeflerinden birisi de tabiatıyla bu şehir olacaktır. Trablus, aşağıda kısaca ifade edileceği üzere, 13. yüzyılda Memlûkler tarafından zaptından Kıbrıs'ın Memlûklerin eline geçmesine kadarki süreçte Memlûk-Haçlı mücadelesinde yoğun saldırıya uğrayan bir yer olarak kaynaklarda geçmiştir. İşte bu çalışmada Memlûklerin Bilâdü'şŞâm sahillerindeki Haçlıları Trablus, Akka, Arvad ve diğer sahil şehirlerinde süpürmeleri ve bunun sonrasında 14. asır boyunca Doğu Akdeniz'e vaki Haçlı saldırıları bağlamında Trablus şehri odağında yaşananların tetkiki yapılmaya çalışılacaktır.

\section{Memlûkler, Haçlılar ve Trablus}

Urfa, Antakya ve Kudüs’ten sonra Doğu'da kurulan dördüncü Haçlı devleti olan Trablus kontluğu bu seferler tarihinde önemli yer tutar. Zira I. Haçlı Seferi'ne katılan Toulouse Kontu St. Gillesli Raymond, Kudüs’te umduğunu bulamayınca İstanbul'a dönüp Bizans İmparatoru Aleksios’tan yardım ister. Ancak 1101 Yılı Haçlı Seferi'nde Merzifon yakınında I. Kılıçarslan karşısında yenilgiye uğraması prestijine ağır bir darbe indirdi. 1102'de Suriye'ye dönüp Tortosa'yı aldı ve Trablus'u kuşattı. Trablus onun ölümünden (1105) sonra 1109'da zapt edildi. ${ }^{1}$ Akabinde Trablus merkezli kontluk kurularak burası dört büyük merkezden ${ }^{2}$ birisi oldu. Haçlılar ile mücadelede Suriye sahili ve buradaki Haçlı yapıları içerisinde şehir önemli bir hedef teşkil etti. Eyyûbîler döneminde şehri Haçlılardan geri alma faaliyetleri başarısız kaldı. Memlûk Sultanı I. Baybars Trablusşam'1 fethetmeye teşebbüs ettiyse de çok müstahkem olan surları karşısında başarılı olamadı.

Sultan el-Melikü'l-Mansûr Kalavûn 1289 yılında oğlu Eşref Halil'i kendisine veliaht ve Emir Baydemir'i nâib ve vezir olarak Kahire'de bırakarak Trablus üzerine sefere çıktı. Aynı zamanda Bilâdü'ş-Şâm'daki kuvvetlere bu sefer doğrultusunda hazırlık yapmaları için emir gönderildi. Önce Dımaşk’a gelen Sultan buradan Trablus'a yöneldi. Bu sırada Haçlıların önemli bir üssü haline gelen Kıbrıs’tan kuşatmaya karşı yardım olarak Trablus'a sekiz adet şevani

1 Işın Demirkent, "Haçlılar”, (DİA), 14, (İstanbul: Türkiye Diyanet Vakfı Yayınları: 1996), 531.

2 Bu kontluk hakkında bk. Birsel Küçüksipahioğlu, Trablus Haçlı Kontluğu Tarihi, (İstanbul: Arkeoloji ve Sanat Yayınları), 2007. 
tipinde gemi gönderildi. Kuşatma esnasında Sultan mancınıkların dikilmesini ve lağımcıların surlarda çalışmaya başlamasını da emretti. 34 gün süren muhasara sonucunda şehir ele geçirildi. Bu esnada şehre doğru 19 mancınık dikilmişti. Şehir ele geçirilince pek çok ganimet ve esir elde edildiği de bilinmektedir. Sultan uygulana gelen adet üzere şehrin yıkılmasını emretti. Trablus gerçekten büyük ve müstahkem surlarla çevrili idi; şehrin surlarının genişliği öyleydi ki üzerinde üç atlı yan yana hareket edebiliyordu. Burada meskûn şehir ahalisi özellikle dokuma sanayinde oldukça ileri durumdaydı ve şehirde dörtbin dokuma aleti bulunuyordu. Bu durum şehrin askeri önemi yanında buraya ayrıca bir ehemmiyet kazandırıyordu. Bu sefer sırasında Trablus yanında Beyrut ve Cebele de ele geçirildi. Trablus zapt edildikten sonra buraya 500 asker, Tablhane emirlerinden 10 kişi, aşarat emirlerinden 15 kişi gönderildi. Şehirde iktalar dağıtıldı. Akabinde Müslümanlar nehir civarında yeni bir şehir inşa ettiler. ${ }^{3} 1289$ 'da Sultan Kalavûn, bu suretle şehri fethetti. Bu esnada şehir halkının bir kısmı gemilerle Kıbrıs'a kaçtı. Böylece Haçlıların İslâm'ın dünyasının içerisinde kurdukları son yapı da ortadan kaldırılmıştır. Antakya'dan sonra Memlûkler son büyük Haçlı siyasi varlığını yok etmekle Suriye kıtasındaki Haçlı varlığını yok olma noktasına getirmişlerdir. Fetih sonrası süreçte Sultan el-Mansûr Kalavûn, Trablusşam'ın surlarını yeni Haçlı Seferleri'ne hedef olmamasıve kullanılamaması için yıktırmış ${ }^{4}$ ve akabinde buradan ayrılmıştır.

Şehrin fethi sonrasında Trablus bugün bulunduğu yerde yeniden inşa edildi. O devirde Trablus el-Müstecde denilen bu yeni șehir Trablus el-Kadime el-Harab olarak bahsedilen eski şehrin yaklaşık dört km uzağına bina edildi. Bu yeni şehir derhal hanlar, çarşılar ve hamamlar ile donatıldı. Haçlıların yeni bir saldırısına karşı kale yeniden tamir edilip, bazı yeni burçlar inşa edildi; Kâdîsâ nehrinin batı yakasında güney bölümünde bir hisar yapıldı. Bunun yanında şehirde medreseler, camiler ve zaviyeler yapıldı. Yeni inşa edilen merkez tüm alt yapıları ile siyasi ve sosyal bakımdan olduğu kadar iktisadi noktada da güçlü bir mekân olarak tebarüz ediyordu. Buranın limanı Hama, Haleb ve Bilâdü'ş-Şâm’ın kuzeyi için bir mal mübadele merkezi idi. Trablus, bu ticari anlamı dolayısıyla Haçlıların hedefi olarak müteakip zamanlarda sürekli saldırılara uğrayacaktı. Ehemmiyetine binaen şehir, Dımaşk ve Haleb’ten sonra Şam bölgesinde üçüncü sıradaydı. Öyle ki şehir sahil memleketlerinin kürsüsü olarak adlandırılmaya başlandı. Böylece Trablus, gerek askerî gerekse de ekonomik önemi dolayısıyla Memlûk idarî yapılanmasında Bilâdü'ş-Şâm'daki altı büyük nâiblikten biri oldu. ${ }^{5}$

1289'da Sultan el-Mansûr Kalavûn tarafından, bahis edildiği üzere, Trablus'un ele geçirilmesinden sonra buraya yerleşen Memlûk kuvvetleri çevre güvenliğine dair olarak

3 el-Makrizî, Takiyy ed-Dîn Ahmed b. Ali, Kitâb es-Sulûk li Marifet-i Duvel el-Mulûk, (Tah. M. Mustafa ZiyadeSaid Abdulfettah Aşûr), I, K.3, (Kahire: 1934), 1958, 746-748; İbn Tağribirdî, Cemâl ed-Dîn Ebû el-Mehâsin Yûsuf, en-Nucum ez-Zahire fi Mulûk Misr ve el-Kahire, VII, (Muhammed Hüseyin Şemseddin), (Beyrut: 1992), 272-273.

4 Kevin Lames Lewis, The Counts of Tripoli and Lebanon, in the Twelfth Century (New York: 2017), 285; Aydin Usta, Haçlı Seferlerinde Kuşatma, (İstanbul: Yeditepe Yayınları, 2015), 224-226.

5 Cengiz Tomar, “Trablusşam”, (DIAA), 41, (İstanbul: Türkiye Diyanet Vakfı Yayınları, 2012), 293; Süleyman Abdu'l-Abdullah el-Harabişe, Niyabet Trablus fi el-Asr el-Memlûkî, (Amman: 1993), 23. 
Haçlılarla olan mücadelelere katıldılar. Trablus ordusu, Emir Seyfeddin Balaban et-Tabbâhî komutasında 1291 'de Akka'nın fethine iştirak etti. ${ }^{6}$ Bu mütemadi hücumlara dayanamayan Haçlılar ellerindeki şehir ve kaleleri boşaltmak zorunda kaldılar. Bunlardan Antartus şehri de Trablus Nâibi tarafından ele geçirildi. Buralardan ayrılan Haçlılar ise Akdeniz'deki küçük Arvad Adasına kaçtılar. ${ }^{7}$ Haçlılar için artık Suriye topraklarında barınmak gittikçe zorlaşacaktı. Memlûkler bu süpürme harekâtı yanında bir takım stratejik önlemler de alıyorlardı. Örneğin Trablus'un şehir ve kalesinin, Haçlıların tekrar dönüp ele geçirdikleri takdirde askeri üs olarak kullanmamaları için, Selahaddin devri ve sonrasında da yapıldığı üzere, yıkıldığı görülmektedir. Aynı şekilde daha sonraları da Sultan el-Eşref Halil'in talimatıyla Cübeyl Şehri de tahrip edilecektir. ${ }^{8}$ Haçlılardan ele geçirilen ve tekrar elden çıkma ihtimali olan yerlerin bir strateji olarak kalesi ve bu manadaki önemli yerlerinin yıkılması Eyyûbîler ve Memlûkler devrinde cari bir usul olarak görülmüştür. Bu itibarla Trablus, Haçlılar ile mücadelede fevkalade önemli bir üs konumunda idi. Doğu Akdeniz'den gelecek saldırılar ve Bilâdü'ş-Şâm sahilindeki mücadelelerde şehir büyük bir rol oynamıştır. Memlûkler devrinde Doğu Akdeniz sahillerine saplanan Haçlı kaması bu suretle Memlûkler tarafından parçalanarak Haçlılar ile mücadele onların Akdeniz' den çıkarılmaları doğrultusunda devam edecektir.

Trablus fethi sonrası Haçlıların karadaki tek üssü Akka idi. 1291 senesinde Sultan Eşref Halil, Akka'nın fethi meselesine eğildi. Emir-i Candâr, Emir İzzettin Aybek el-Efrem'i Şam bölgesine yollayarak mancınıklar hazırlanmasını emretti ve ardından kendisi de bölgeye gitti. Mancınıklar hazırlandıktan sonra ordu harekete geçti. Şam emirlerinden Emir Alamüddin Sancar ed-Devadarî onunla birlikte idi. Şam Nâibi Emir Lâçin, Kahire'den Emir Seyfeddin Tuğrul el-Eyganî orduya katılmak üzere harekete geçti. Hama Emiri el-Muzaffer askerleri, mancınıklar ve sair silahlarla buraya geldi. Emir Seyfeddin Balaban Trablus ve sair kalelerde bulunan askerler ile orduya katıldı. Bütün nâibler askerleriyle Akka'ya yöneldiler. Sultan Eşref Halil Beynel-Kasreyn'de babasının mezarı yanında Akka'ya gideceği vakit ulema, kadılar, ayan ve mutasavvıfların(fukara) çadırında (el-Kubbe el-Mansûriyye)'de toplanmalarını istedi. Burada sabaha kadar büyük törenler yapıldı ve fakir fukaraya para dağıtıldı. Bu işler bitince Cuma sabahı Kale’ye döndü. Sultan harekete geçerek Kahire'den önce Dımaşk'a ulaştı. Buradan Akka önüne geldi. Bu esnada sayısı 92'yi bulan mancınık kuruluyordu. Bütün bu mancınıklar dört günde kuruldu. Bu suretle kuşatma başlamış oldu. Haçlılar tarafından da şehre büyük yardım gönderiliyordu. Zira Akka karadaki son üsleriydi. Kuşatma sırasında lağımcılar (nukûb) surların altını kazıyorlardı. Cuma günü Sultan askerleriyle şehre girmeye azmetti. 300 devenin taşıdığı büyük davullar (kösat) hazırlandı. Hepsinin bir anda çalınması emredildi. ${ }^{9} \mathrm{Bu}$

6 Ebu'l-Fida, Muhtasar fi Ahbar el-Beşer, VII, Tah. Edib el-Ârif ez-Zeyn, (Beyrut: 1961), 25, 31; İbnü'l-Verdî, Tetimettü'l-Mutasar fi Ahbar el-Beşer, II, Tah. Ahmet Rifat el-Berdavî, (Beyrut: 1970), 336-337; İbnü'l-Furat, Tarihu Duvel ve'l-Mulûk, VIII, Tah. Konstantin Zurayk, (Beyrut: 1936-1942), 109-112; el-Harabişe, Niyabet Trablus, 63-67.

7 “Arvad Suriye'nin Tartus şehrine 3 km mesafede olan bir adadır.", Ana Britannica, 2, (İstanbul: 1992), 367.

8 el-Makrizî, Kitab es-Sulûk, I, K.3, 764-765.

9 Burada mehterin Türk savaş düzeni içindeki yerini çok açık bir şekilde görmek mümkündür. 
davullar ile Akka halkı istendiği üzere korku ve şaşkınlığa düştü. Güneşin doğuşuyla birlikte asker şehre doğru yürüdü. Güneş çok yükselmeden es-Sanâcık el-İslâmiyye/İslâm'ın sancakları şehir surlarında dalgalanmaya başladı. Şehirdeki Haçlılar deniz tarafından kaçtılar ve çok sayıda kayıp verdiler. Müslümanlar, çok sayıda esir ve ganimet elde ettiler. Akka kuşatması 44 gün sürmüştü. Tarblus’ta olduğu gibi Haçlı hedefi hâline gelmemesi için yıkıldı, surları tahrip edildi. Bu esnada Sur, Hayfa, Aslis ve Sayda'da bazı yerler savaşsız ele geçirildi. Sur ve Sayda ele geçirilince zafer davulları vuruldu. Buralar da aynı sebeple yıktırıldı. ${ }^{10}$ Trablus ve Akka'yı kaybeden Haçlılar artık Doğu Akdeniz'de adalarda tutunmaya çalışacaklardır. Bunlardan ilki Suriye kıyılarına çok yakın olan Arvad Adası'dır.

Trablus merkezli harekât sonucunda Arvad Adasına sığınan Haçlılar burada bir sur ve kale inşa ederek adayı karargâh hâline getirmişlerdi. Silahlandırılan ada üzerinden Haçlılar, Şam sahiline ve özellikle de Trablus’a saldırılarda bulunmaya başladılar. Haçlılar kayıplarını telafi için artık deniz üzerindeki üslerden karayı vuracaklardı. Antartus ve Trablus coğrafi konumları nedeniyle bu saldırıların özel hedefi durumundaydı. Haçlılar, yol kesme ve gelen-giden ticaret gemilerine saldırılar şeklinde harekât düzenlemeye başladılar. Bahsedilen olaylar, bu meyanda Trablus Valisi'ne ${ }^{11}$ ulaşan bilgiye göre Haçlıların eline esir düşen Müslüman tüccar sayısı 300 idi. ${ }^{12}$ Saldırılar ve uğranan zayiat üzerine Trablus nâibi Emir Seyfeddin Esendemir Sultan enNâsır Muhammed b. Kalavûn'dan Arvad Adası'nın fethi için yardım istedi. Karşı saldırılar ile müteakip dönemde Haçlıların Doğu Akdeniz'den çıkarılmaları söz konusu olacaktır. Nâibin talebine derhal olumlu cevap veren Sultan, Emir Seyfeddin Kehradaş el-Mansûrî1 ${ }^{13}$ komutasında bir donanmayı Trablus'a yolladı. Şehre gelen birlikler burayı karargâh hâline getirirken onlara gönüllüler, Trablus’taki denizciler yanında Trablus ordusu da Nâib komutasında katılarak Tartus'un güneyinden, karadan, Arvad kuşatmasına iştirak ettiler. Emir Kehredaş adadakilerin bir gaflet anından yararlanıp saldırıya geçerek adayı fethetti. Ayrıca pek çok Haçlı öldürüp esirler alırken burada esir düşen Müslümanları özgürlüklerine kavuşturdu. Memlûk Komutanı elde edilen ganimetleri askerlere dağıtıp beşte birini de Sultan'a Kahire'ye yolladı, esirler ise Şam' da bulunan kalelere dağıtıldı. ${ }^{14} 1302$ senesinde böylece Arvad Adası Trablus'a bağlandı. Fethi haber vermek üzere Kahire'ye haberci gönderildi. Zafer davullar vuruldu' ${ }^{15}$, halk Haçlı kalıntılarının Şam Bölgesi sahillerinden temizlendiği için sevindi. 1099'da başlayan Haçlı macerası böylece bölgede nihayete eriyordu. 14. asrın başında Bilâdü’ş-Şâm'da yaşanan bu gelişmeler bir mücadelenin sonunu teşkil ederken bu yüzyıl içerisinde söz konusu olacak yeni Haçlı saldırılarının da başlangıcına zemin oluşturmaktaydı.

10 el-Makrizî, es-Sulûk, I, K. 3, 763-766; Usta, Haçlı Seferlerinde Kuşatma, 226-238.

11 Ebu'l-Fida, el-Muhtasar, VII, 57; İbnü'l-Verdî, Tetimettü'l-Mutasar, II, 357; el-Makrizî, es-Sulûk, I, K.3, 928.

12 İbn Hacer, ed-Dürer el-Kâmine fi Ayan Miet Sâmine, III, Tah. Seyyid Cad el-Hakk, (Kahire: 1966-1967), 355.

13 el-Makrizî, es-Sulûk, I, K.3, 923, 927-928; İbnü'l-Verdî, Tetimettü'l-Mutasar, II, 357, 358.

14 Ebu'l-Fida, Muhtasar, VII, 57; İbnü'l-Verdî, Tetimettü'l-Mutasar, II, 357, 358; el-Makrizî, es-Suluk, I, K.3, 923-23, 928-29.

15 el-Makrizî, es-Sulûk, I, K.3, 929. 


\section{14. Asır ve Sonrası Trablus Üzerinden Cereyan Eden Mücadele}

Haçlı saldırıları Arvad Adası'nın fethi ile son bulmadı. Bilakis 14. ve 15. asırlarda Haçlı saldırıları kesilmeden devam etti. 14. asır Haçlıların Doğu Akdeniz’e Anadolu, Mısır ve Suriye sahillerine yeni bir Haçlı düşüncesiyle saldırılarının olduğu dönemdir. İşte Trablus bu saldırıların özel hedeflerinden biri oldu. Bu cümleden olarak, Haçlıların Suriye'den denize dökülmeleri sonrasında, 1334 senesinde, Trablus'a saldıran bir Haçlı grubu da yenilgiye uğratılacaktır. Mücadelenin sonucunda Haçlıların pek çoğu öldürüldü. Hayatta kalanlar ise esir edildiler. Yine mücadelenin akabinde İslâm ordusunun eline pek çok ganimet geçmiştir. ${ }^{16} \mathrm{Bu}$ olayda şehre saldıran geminin kaptanı yakalanıp Trablus Nâibi Emir Cemaleddin Akkuş el-Efrem'e getirilerek bu hareketinin sebebi sorgulanmış, kaptan, kendisini savunmak için bölgeye ticaret için geldiğini söylemiştir. Müslümanların kendisine saldırısından korkarak bazılarını öldürüp savunma amaçlı olarak çarpıştığını ve onların mallarını aldığını ifade ile savunmasını yapmıştır. Trablus tüccarları onun bu sözlerine kızıp kendisinin korsanlık, yağma için geldiğini söyleyip ona kızdılar. Kendisinin bir yıl önce de bölgeye saldırdığını söylediler. Bu durumda kaptanın gemisine el konuldu. ${ }^{17} \mathrm{Bu}$ olay Sultan'a bildirildiğinde kaptanı kendisine yollamalarını istemiş ve kaptanı dinleyince onun haklı olduğunu düşünerek gemisinin iadesi emrini vermişti. Buna onay vermeyen Nâib, Sultan'ın istediğini yapmamış ve sonuçta nâiblikten alınarak Şam'da tutuklanmıştır. ${ }^{18}$ Bu tip faaliyetlerin Haçlılar için nabız yoklama, şehirdeki durumu anlama ve daha büyük seferler için zemini tetkik maksatlı girişimler olduğu düşünülebilir. Ayrıca bölgeye korsanlar üzerinden saldırarak zarar vermek taktik bir hareket olarak kayıt edilmelidir.

Haçlı saldırıları ise bu süreçte kesilmeden devam etti. 1355 senesinde Haçlılar, yeniden birkaç gemiyle Trablus'a saldırdılar ve şehir halkının bir kısmı da onların eline esir düştü. Aldıkları mal ve yiyecek karşılığından esirleri bırakan Haçlılar, başarılarından cesaret alarak 1356'da yeniden Trablus ve ona komşu bazı köylere saldırdılar. Trablus askerinin kendilerine başarıyla mukavemeti üzerine herhangi bir kazanç elde edemeden çekildiler. ${ }^{19}$ Haçlıların bu devirdeki yeni karargâhları Kıbrıs Adasıydı. Karadaki üslerini kaybeden Haçlılar için Kıbrıs artık Haçlı operasyonlarının merkezi olacaktı. Memlûkler nihai olarak 15. yüzyılda adayı ele geçirip mevcut tehlikeyi bertaraf edeceklerdir.

1365 senesinde Haçlılar bir kere daha Trablus’a saldırdılar. Trablus limanındaki Müslümanlara ait gemileri ele geçirdiler. Buradaki gemileri yakıp üç kişiyi de esir aldıkları kaynaklarda kaydedilmektedir. Haçlılar saldırıdan dönüşleri sırasında şehir dışında olduğu anlaşılan nâib ve Trablus kuvvetlerinin her hangi bir müdahalesine uğramadan üslerine döndüler. ${ }^{20}$

1365 yılı, Haçlıların Doğu Akdeniz'de İslâm dünyasına saldırılarının zirve yılıdır. Mısır, bu noktada büyük bir saldırıya uğramıştır. 1365 senesinde Haçlıların İskenderiye’ye saldırısından

16 el-Makrizî, es-Sulûk, II, K.2, 379; İbn Hacer, ed-Dürer, I, 423.

17 el-Makrizî, es-Sulûk, II, K.2, 379.

18 el-Makrizî, es-Sulûk, II, K.2, 379.

19 el-Makrizî, es-Sulûk, III, K.1, 27.

20 el-Harabişe, Niyabet Trablus, 63-64. 
sonra Sultan el-Melik el-Eşref Şaban, sefer hazırlığı yapmıştır. Sultan, hem bu saldırının hem de Mısır ile Şam sahillerinde vaki olan saldırıların intikamını almak için Kıbrıs Adası'na bir sefer düzenlemeyi hedeflemiştir. Sultan, Kıbrıs'ı ele geçirmek için Atabek el-Asakir Emir Yelboğa el-Ömerî komutasındaki bir orduyu sefere çıkarmıştır. Yine Sultan, savaş gemilerinin yapılması ve sefere hazır edilmeleri için de bir takım faaliyetler içinde bulunmuştur. $\mathrm{Bu}$ doğrultuda ilk olarak yeni gemilerin inşa edilmesi için Antakya dağlarından ahşap malzemelerin tedarik edilmesini emretmiştir. İkinci olarak ise Trablus Nâibliği gibi sahil niyabetlerine savaş gemisi hazırlamalarını ve Kıbrıs gazasına teçhiz olmalarını bildirmiştir. Lakin tüm çalışmalar Emir Yelboğa'nın 1366'da vefatıyla yarım kaldı. ${ }^{21}$ Bu sırada Haçlılar, Memlûkler ile sulh için gayret gösteriyorlardı. Hatta Sultanı düşüncesinden caydırmak için 116 gemilik bir filoyu Lesparreli Florimont komutasında Trablus'a saldırıya yolladılar. Vaki firtına nedeniyle bunlardan sadece 15'i şehre ulaşabildiyse de bir çatışma olmadan Haçlılar Kıbrıs'a döndüler. ${ }^{22}$ Memlûkler, Haçlıların İskenderiye saldırısını ve tahribini hiç unutmayacaklardır. Hatta bu saldırının intikamını almak için önce Ermeni Baronluğu'na daha sonra ise Kıbrıs'ta bulunan Haçlı varlığına son vereceklerdir.

Bu süreçte Haçlıların İskenderiye saldırısı başarısız olunca Trablus Haçlıların ana hedefi hâline gelmişti. Kıbrıs adasına yakınlığı, Şam sahilinin tam ortasında olması ve ticari konumu nedeniyle şehir, Haçlılar için stratejik önemde idi. Önemli bir ticaret merkezi olan Trablusşam 15. yüzyılda Avrupa ticaretine açık olma özelliğini de sürdürüyordu. Bilhassa Fransa ve Cenova ile sıkı ticarî ilişkileri vardı. Doğu Akdeniz'de ticaret gemilerinin başlıca uğrak yeri durumundaydı. İhraç maddeleri içinde ipekli kumaşlar önemli bir yere sahipti. Akdeniz ticaretiyle uğraşan devletlerin burada birer temsilcisi bulunuyordu. ${ }^{23}$ Haçlilar siyasi olduğu kadar ekonomik anlamı da olan yerlere saldırarak Doğu Akdeniz'deki İslâm gücüne darbe indirip çok yönlü zarar vermek istiyorlardı.

$\mathrm{Bu}$ gelişmeler sırasında, Haçlılar boş durmuyor, Lusignan hanedanından olan Kıbrıs Kralı, Trablus'taki yerel bilgi kaynakları ile yazışarak şehrin imkânları ve ele geçirilme firsatları hakkında bilgi alıyordu. Bu hazırlıkları tamamlayan Kral, nihayet 1367'de 130 ile 200 arasında değişen muhtelif tür gemilerden oluşan bir donanmayla şehir üzerine sefere çıktı. Bu kuvvetlerin içinde Rodos Kralı ve Tapınak Şövalyeleri ki kuvvetleri 116 bin kişiden oluşan Ceneviz, Venedik, Giritliler, Fransızlar, Macarlardan ve Kıbrıslılardan ${ }^{24}$ müteşekkil Haçlı birliğinden oluşan askerler de vardı. Bu saldırının vakti tabi ki tesadüfen seçilmemişti.

21 el-Makrizî, es-Sulûk, III, K.1, 112-113; Salih b. Yahya, Tarihu Beyrut, Tah. Francis Hours-Kemal Salîbî, (Beyrut: 1969), 52-53, 213.

22 Nicholas Coueras, "The perception and Evaulation of Foreign Soldiers in the Wars of King Peter I: The Evidence of the Cypriot Chronicles and its Shortcomings", The Medieval Chronicle II, Ed. Erik Kooper-Sjoerd levelt, (Leiden: 2018), 117; Kenneth M. Setton, Papacy and Levant, V. 1, (USA: 1976), 279; el-Harabişe, Niyabet Trablus, 64.

23 Tomar, “Trablusşam”, 293.

24 el-Makrizî, es-Sulûk, III, K.1, 149; İbn İyas, Bedai ez-Zuhur fi Vekai ed-Duhûr, I, Tah. Muhammed Mustafa Ziyade, (Kahire: 1960-1973), 65. 
Trablus'ta o sırada azledilen şehir nâibi yoktu ve askerler yeni Nâib Seyfeddin Mencek’i karşılamak için şehirden çıkmışlardı. İşte tam bu sırada başlayan bu saldırıda şehre yaklaşan Haçlı donanmasına ilk anda şehir halkı, Türkmenler ve Mağriblilerden bir grup karşı koymaya çalıştı ancak mevcut kuvvetlerin bu büyük güce mukavemet edememesi üzerine Haçlılar şehre girip bir gün ve gece burada kalıp yağma yaptılar. Haçlılar işgalleri sırasında şehirde hapis olan Kıbrıs Kralı'nın kız kardeşini kurtarmak için hapishaneye yöneldilerse de buradaki muhafızlar bu kişiyi öldürdüler. Bu esnada İbn Malik ve İbn Sahr komutasında bölge Türkmenlerinden yardım geldi. Haçlılarla Müslümanlar arasında çok şiddetli çatışmalar oldu ve kaynağa göre 40 Müslüman şehit oldu. Binlerce Haçlı da bu çatışmalarda öldürüldü. Haçlı Kralı da bu çarpışmalarda yaralandı. Nihayet Haçlılar bu direniş karşısında çekilmek zorunda kaldılar ve yağmaladıkları pek çok şeyle Kıbrıs'a geri çekildiler. ${ }^{25}$ Trablus, böylece çok büyük bir Haçlı saldırısını savuşturmuş, İskenderiye tahribinden sonra ikinci büyük bir darbeden kurtulmuştur. Haçlılar askeri ve ekonomik merkezleri tahrip ile Müslümanları zaafa düşürmeye çalışıyorlardı. İskenderiye saldırısı sırasında çok sayıda dokuma tezgâhının tahrip edildiği ve bunun Memlûk ekonomisine telafisi zor zararlar verdiği bilinmektedir.

Bu saldırılar karşısında Haçlılar ters yüz edildilerse de amaçlarının tahakkuku için denemelere devam ettiler. Kıbrıs'ta bulunan Haçlı Kralı bu başarısız seferden dolayı oluşan zararlarını telafi ve borçlarını ödemek için Trablus’un kuzeyindeki şehirlere saldırmaya karar verdi. Bu cümleden Antartus'a saldırdı. Burayı yaktı ve Sultan'ın Kıbrıs seferi için oluşturulan donanma için hazırlattığı ahşap malzemesini tahrip etti. ${ }^{26}$ Kıbrıs Kralı buradan Markiyye’ye yönelerek şehre saldırdıysa da İbn Kankar komutasından Türkmenler onu geri çekilmek zorunda bıraktı. Bundan sonra Belenyas'a yönelen Kral, ahalisi Markab Kalesi’ne sığındığından burayı boş buldu. Bir gün gece burada kaldı ve şehri yaktı. Ordu buradan Cebele'ye yöneldi. Oradan da Lazkiye'ye girdi. Limana giren üç gemi Müslümanlar tarafından etkisiz hâle getirildi ve Trablus'tan 1367 seferinde yağmalanan bazı eşyada bu sırada ele geçirildi. ${ }^{27}$ Haçlılar müteakiben Haleb'e bağlı olan Ayas (Yumurtalık) şehrine yöneldiler. Haçlıların bu tahrip ve yağma odaklı ilerleyişleri sırasında Trablus askeri, Nâib Emir Seyfeddin Mencek komutasında onları takip ediyordu. Takipçi birlikler 5000 Haçlıyı öldürmeye muvaffak oldular. Geride ise Haçlıların 30.000 kişilik kuvveti kalmıştı. ${ }^{28}$ Haleb Nâibi'nden gelen yardımın da yetişmesiyle Haçlılar Kıbrıs'a dönmek zorunda kaldılar. Söz konusu saldırı Haçlıların hedefinin Trablus olduğunu bir kere daha açıkça göstermiştir. Bu dönemde Haçlılar stratejileri bağlamında Anadolu sahilleri de dahil olmak üzere tüm Doğu Akdeniz sahillerine saldırılarda bulundular. Bu cümleden olarak, Trablus'a saldırıyla yetinmeyen Haçlılar Lazkiye'ye kadar olan sahil bölgesine hücum edip ve büyük tahribata yol açmışlardı. Bahsedilen meselenin teyidi olarak 1368 senesinde

25 el-Makrizî, es-Sulûk, III, K.1, 149; Said Abdulfettâh 'Aşûr, Kubrus ve Hurûbu ’s-Salibiyye, (Kahire: 1957$), 77$.

26 'Aşûr, Kubrus ve Hurûbu's-Salibiyye, 77; el-Harabişe, Niyabet Trablus, 65.

27 el-Harabişe, Niyabet Trablus, 65.

28 el-Makrizî, es-Sulûk, III, K.1, 150. 
yeniden saldırıya geçen Haçlılar el-Betrun, Antartus ve Lazkiye'ye saldırırlarsa da bir başarı elde edemeden Kıbrıs'a döndüler. ${ }^{29}$

1370’de Memlûkler ile Haçlılar arasında vaki olan antlaşmaya rağmen Cenevizliler, Şam ve Mısır sahillerine Akdeniz'de ticari faaliyeti baltalamak ve buna ilave en büyük rakipleri Venediklilerin bu ticaretten elde ettikleri kâra zarar vermek maksadıyla saldırılar düzenlediler. $\mathrm{Bu}$ Ceneviz harekâtına Rodos, Katalan ve Kıbrıs korsanlarından bazı gruplar da katılmıştı. ${ }^{30}$ Doğu Akdeniz' deki mücadeleye ve Haçlı teşebbüslerine zamanın bölgeyle ilgili bütün güçleri katılıyordu. 14. yüzyıl bu bakımdan 13. yüzyılda klasik çağı kapanan Haçlı saldırılarından sonra büyük saldırıların düzenlendiği bir yüzyıl olarak değerlendirilmelidir.

Haçlı saldırıları bu asırda muhtelif zamanlarda tekrar ediyordu.1378 yılında Dımaşk Nâibi Emir Beydemir el-Harezmî'nin Sultan El-Mansûr Ali b. Şaban'a isyan etmesinden yararlanan Haçlılar Trablus'u 10 gemilik bir donanma ile işgal ettiler. Trablus Nâibi Yelboğa en-Nasırî, Türk savaş taktiğini -Turan- uygulayarak, onlara karşı durarak onları sahte bir ricatla şehrin içine çekip kuşattı, etraflarını sardı; birçoğu öldürülen Haçlılardan esir düşenler de oldu. Geri kalanalar ise gemilerine binip kaçtılar. ${ }^{31}$ Yine 1387 'de Haçlılar şehre saldırdığında şehrin nâibi Gümüşboğa el-Hamevî, taktik uygulayarak tedricen yenilmiş gibi geri çekildi. Gemilerinden iyice uzaklaştıklarında ise etraflarını kuşatarak Haçlılara ağır darbe indirirken, pek çoğunu öldürdü ve üç gemiyi de ele geçirdi. ${ }^{32}$ Bundan üç sene sonra Haçlilar özel olarak Trablus nâibliğinde umumi olarak ise Memlûk Devleti'ndeki Berkuk ile Yelboğa-Mintaş arasındaki çekişmeden doğan karışıklıktan yararlanarak şehri işgal ettiler. 1390'da 70 gemiden oluşan bir donanma ile şehri ele geçirdiler. Lakin hava şartlarının uygunsuzluğu nedeniyle bir sonuç alamadan döndüler. ${ }^{33} 1401$ senesinde Haçlıların ticaret gemilerini bahane edip şehre saldırdıkları görülmektedir. ${ }^{34}$ Haçlılar Müslümanlar arasındaki her türlü iç karışıklıktan saldırı vesilesi olarak yararlandılar. Bundan iki yıl sonra, 1403'te, Haçlılar De Bucic Autt komutasında Trablus'a saldırdılar. Kendisine Kıbrıs Kralı II. John ve Rodos’ta bulunan Tapınak Şövalyeleri eşlik ediyordu. Haçlılar, bu sefer Emir Cekem ${ }^{35}$ ile Baalebek’te çatışan Trablus Nâibi Emir Demürtaş el-Muhammedî’nin yokluğundan yararlanarak 30 gemilik bir donanma ile şehrin üzerine geldiler. Halk şehre saldıran bu güce mukavemet ederek şehre girmelerini engellediler. Emir Demürtaş Emir Şeyh Mahmûdî’den yardım isteyince O hemen Haçlılara karşı harekete geçti. Onun gelişini öğrenen Haçlılar güneye yönelerek Beyrut ve Sayda’yı yağmaladılar. Lakin burada da mukavemetle karşılıp Trablus tarafına dönünce nâib komutanlığındaki kuvvetlere

29 el-Makrizî, es-Sulûk, III, K.1, 285-286.

30 Said Abdulfettâh 'Așûr, el-Asr el-Memâlîkî fì Misr ve'ş-Şam, (Kahire: 1994), 268; el-Harabişe, Niyabet Trablus, 65.

31 el-Makrizî, es-Sulûk, III, K.1, 335; Salih b. Yahya, Tarihu Beyrut, 53.

32 el-Makrizî, es-Sulûk, III, K.2, 562; Türk savaş taktiğini bu vesile görmek tarihin bir cilvesidir.

33 el-Makrizî, es-Sulûk, III, K.2, 593, 594, 611, 723; İbnü'l-Furat, Tarihu Duvel, IX, 54, 206, 221.

34 el-Makrizî, es-Sulûk, III, K.2, 1079; 'Aşûr, el-Asr el-Memâlikî, 269.

35 Bu çatışmalar hakkında ayrıntılı bilgi için bk. Murat Zengin, "Memlûklü Devlet Adamı Emir Çekem ve İsyanları", History Studies, XI/5, Ekim 2019, 1861-1863. 
yenilip Kıbrıs'a kaçtılar. ${ }^{36}$ Memlûkler Kıbrıs merkezli Doğu Akdeniz'deki Haçlı tasallutuna karşı onların karargâhlarını birer birer yok ederek mukabele ettiler. Kıbrıs'a düzenlenen seferler süreçteki en önemli hareketlerden olacaktır. 1424'de Trablus kuvvetlerinin de Kıbrıs'ın ele geçirilmesi için düzenlenen mevzu bahis sefere katıldığı görülür. Mukabil olarak Haçlılar 1425 senesinde hücumlarına devam ederek Trablus sahillerine saldırıp Sur'a hücum ettiler. Trablus ve Cebele arasında vuku bulan çarpışmada Haçlılar yenilgiye uğradılar. ${ }^{37}$ Trablus artık Kıbrıs Seferleri'nin ana üssü hâline gelmişti. 1425 ve 1426 'daki seferlere Trablus'tan 300 süvariye yakın askerin iştirak ettiği kaynaklarda ifade edilmektedir. ${ }^{38}$

Haçlı Seferleri'nin bu son devresinde Memlûklerin Haçlılara indirdiği ağır darbeler sonucu Haçlılar, Kıbrıs Adası merkezli olmak üzere deniz üzerinden Avrupa'dan gelen desteklerle mücadelelerini sürdürmeye çalışmışlarsa da 15. yüzyılın başlarında Kıbrıs Adası'nın Memlûkler tarafından fethi Haçlıları daha geriye itecektir. Kıbrıs Seferi'nden önce ise 1365 İskenderiye saldırısının intikamı Ermeni kontluğundan alınarak hesap görülmeye başlanacaktır. Memlûkler genel olarak 14. yüzyıl Doğu Akdeniz’e vaki saldırı ve tasalluta karşı ilk karşı harekâtı Haçlıların önemli bir üssü hâline gelen Ermeni Baronluğu üzerine yapacaklardır. Haçlılar vesilesi ile krallık statüsüne ulaşan buradaki Sis merkezli yapılanma Memlûklerin kuzey sınırı açısından olduğu kadar Haçlı mücadelesinde de önemli bir risk bölgesi oluşturuyorlardı. İşte Memlûkler, Haçlı Seferleri tarihinin bu kırılma noktasında Antakya ve Trablus kontluklarına indirdikleri darbe sonrasında önemli bir Haçlı merkezi hâline gelen Ermeni Krallığı'nı ortadan kaldırmışlardır.

\section{Sonuç/Conclusions}

Sonuç olarak, Doğu Akdeniz bölgesi burada İslâm ve Türk merkezli yapıların varoluşu ve hâkimiyetleri ile birlikte bir mücadele sahası oldu. Haçlı Seferleri sonucu bugünkü Suriye ve Lübnan kıyılarında kurulan Haçlı devletçikleri nihai olarak Memlûkler tarafindan yıkıldılar. Akabinde ise Haçlılar özellikle 14. asırda yoğunlaşan saldırılarını sürdürecekler ve Memlûkler Doğu Akdeniz'de ciddi bir mücadele ile bu saldırıları püskürteceklerdir. Haçlılar bu dönemde Doğu Akdeniz'deki hücumlarını askerî ve ekonomik açıdan zarar verme amaçlı gerçekleşiyorlardı. İstikrarsızlaştırdıkları bölgeye geri dönmelerinin yahut Doğu Akdeniz'deki varlıklarının zayıflatılmış, tahrip edilmiş ve bölünmüş yapılar karşısında daha güvende olacağını düşünüyorlard1. Memlûk galibiyetinin önemli sebeplerinden birisi Memlûklerin güçlü idari, sosyal ve askeri düzenleri ve Bilâd eş-Şam'da kurdukları yapının ahenkli çalışmasıdır. Trablus, bu meyanda askeri ve ekonomik önemine binaen saldırılardan doğrudan etkilenmiş ve Memlûklerin savunma hattının merkezî şehirlerinden birisi olmuştur. Nihayet bu gelişmelerin sonunda, daha önceki çalışmalarımızda ele aldığımız ${ }^{39}$ Kıbrıs'ın Barsbay zamanında fethi ile Doğu Akdeniz Haçlılara kapatılmıştır. Trablus, Akka gibi şehirlerin düşmesi ile karadaki imkân ve kabiliyetlerini

36 el-Makrizî, es-Sulûk, III, K.2, 1164-1165; İbn İyas, Bedai ez-Zuhur, I, 281-282.

37 el-Makrizî, es-Sulûk, IV, K.2, 672, 687-689; Salih b. Yahya, Tarihu Beyrut, 242.

38 el-Makrizî, es-Sulukk, IV, K.2, 689; Salih b. Yahya, Tarihu Beyrut, 243.

39 Bk. Altan Çetin, "Memlûklerin Kıbrıs ile İlişkileri”, Adalya, XIV, (İstanbul: 2011), 327-344. 
yitiren Haçlılar, sonraki süreçte deniz üzerinden korsanlar ve doğrudan saldırılar ile bölgeye dönmeye çalışmışlarsa da Osmanlı Devleti'nin 20. asır başlarında bölgeden çekilmesine kadar bu fiilen mümkün olmamıştır. Haçlı-Memlûk mücadelesini ve Müslümanların başarılarını gerçek saikleriyle doğru anlamak gelecekteki muhtemelleri düşünürken şüphesiz yol açıcı olacaktır.

Hakem Değerlendirmesi: Dış bağımsız.

Çıkar Çatışması: Yazar çıkar çatışması bildirmemiştir.

Finansal Destek: Yazar bu çalışma için finansal destek almadığını beyan etmiştir.

Peer-review: Externally peer-reviewed.

Conflict of Interest: The author has no conflict of interest to declare.

Grant Support: The author declared that this study has received no financial support.

\section{Kaynaklar/References}

Aşûr, Said Abdulfettâh. Kubrus ve Hurûbu 'S-Salibiyye, Kahire: 1957. . el-Asr el-Memâlîkî fì Misr ve 'ş-Şam. Kahire: 1994.

Coueras, Nicholas. "The perception and Evaulation of Foreign Soldiers in the Wars of King Peter I: The Evidence of the Cypriot Chronicles and its Shortcomings." The Medieval Chronicle II, (Ed. Erik KooperSjoerd levelt), Leiden: 2018.

Demirkent, Işın. "Haçl1lar." Türkiye Diyanet Vakfi İslâm Ansiklopedisi (DIAA) 14, (1996): 525-546.

Ebu'l-Fida. Muhtasar fi Ahbar el-Beşer. VII, (Tah. Edib el-Ârif ez-Zeyn), Beyrut: 1961.

el-Harabişe, Süleyman Abdu'l-Abdullah. Niyabet Trablus fi el-Asr el-Memlûkî. Amman: 1993.

el-Makrizî, Takiyy ed-Dîn Ahmed b. Ali. Kitâb es-Sulûk li Marifet-i Duvel el-Mulûk. (Tah. M. Mustafa ZiyadeSaid Abdulfettah Aşûr), I, K.3, Kahire: 1934, 1958.

İbn Hacer. ed-Dürer el-Kâmine fi Ayan Miet Sâmine-III. (Tah. Seyyid Cad el-Hakk), Kahire: 1966-1967. İbn İyas. Bedai ez-Zuhur fi Vekai ed-Duhûr-I. (Tah. Muhammed Mustafa Ziyade), Kahire: 1960-1973.

İbn Tağribirdî, Cemâl ed-Dîn Ebû el-Mehâsin Yûsuf. en-Nucum ez-Zahire fi Mulûk Misr ve el-Kahire-VII, (Muhammed Hüseyin Şemseddin), Beyrut: 1992.

İbnü'l-Furat. Tarihu Duvel ve'l-Mulûk-VIII. (Tah. Konstantin Zurayk), Beyrut: 1936-1942.

İbnü'l-Verdî. Tetimettü'l-Mutasar fi Ahbar el-Beșer-II. (Tah. Ahmet Rıfat el-Berdavî), Beyrut: 1970. Küçüksipahioğlu, Birsel. Trablus Haçlı Kontluğu Tarihi. İstanbul: Arkeoloji ve Sanat Yayınları, 2007.

Lewis, Kevin Lames. The Counts of Tripoli and Lebanon, in the Twelfth Century. New York: 2017.

Salih b. Yahya. Tarihu Beyrut. (Tah. Francis Hours-Kemal Salîbî), Beyrut: 1969.

Setton, Kenneth M. Papacy and Levant. V. 1, USA: 1976.

Tomar, Cengiz. "Trablusşam”, Türkiye Diyanet Vakfi İslâm Ansiklopedisi (DIAA), 41, (2012): 292-294.

Usta, Aydın. Haçlı Seferlerinde Kuşatma. İstanbul: Yeditepe Yayınları, 2015.

Zengin, Murat. "Memlûklü Devlet Adamı Emir Çekem ve İsyanları", History Studies, XI/5, Ekim 2019. 
